\title{
BIODIVERSITIES AND ABUNDANCE OF PLANKTON AND BENTHOS IN LAKE JEMPANG, WEST KUTAI
}

\author{
GHITARINA, DENI UDAYANA, AND HENNY PAGORAY
}

\author{
Faculty of Fishery and Marine Sciences, Mulawarman University, Indonesia
}

\begin{abstract}
The discharge of pollutants which is derived from industrial waste, such as oil and gas, palm oil, coal mining, and domestic activities, into the Mahakam river basin may contribute to the declining of water quaity of Mahakam river basin including Lake Jempang in West Kutai Regency. The study aimed to identify the condition of plankton and benthos in Lake Jempang. The study was conducted through survey, observation, and measurement of plankton and benthos communities. The results showed that the abundance, diversity, equitability and the dominance indexes of plankton and benthos are still relatively moderate.
\end{abstract}

Keywords: Lake Jempang, plankton, benthos, biodiversity, abundance

\section{INTRODUCTION}

Lake plays an important role in ecosystems. Many studies have reported that lake and its surrounding area is one of the most threatened ecosystems on earth. According to experts, many lake ecosystems in the world are currently facing serious problems that lead to degradation and extinction of various lakes (Angeler et al., 2015). Lakes on Mongolian Plateau experience reduction due to development around the lake (Taoa et al., 2015). Rapid development in the areas around lakes significantly contributes to the degradation of the lakes and decrease their carrying capacity. Lakes in China for example have experience deterioration as a result of rapid development after following economic growth (Wang et al., 2015). Changes of Lake Tana Basin as the cause of development around the lake have been identified by Abate et al. (2017). One cause of declining carrying capacity of an environment is addition of the organic load that can stimulate aquatic productivity and ultimately could disrupt aquatic biotic and abiotic characteristics of the environment, including plankton as one oftrophic level components.

Correspondence Author: Ghitarina. Faculty of Fishery and Marine Sciences, Mulawarman University.

Email: ghitarina@fpik.unmul.ac.id
Changes in productivity that occur in the lake associated with nutrient input due to human activity, commonly called eutrophication. This nutrient element is usually nitrogen in the form of nitrate and phosphorus in the form of phosphate derived from waste, industrial tributaries or agriculture fertilizers, or from all three. Phosphate and nitrate in the waters will stimulate the fertility of the waters. The high fertility of waters is by the growth of phytoplankon in the water surface area, the impact of the abundance of phytoplankton is to reduce the penetration of light into the water column used as photosynthetic process which will produce dissolved oxygen (Fachrul et al., 2005 in Risamasu and Prayitno, 2011).

High levels of total nitrogen and phosphate are the main nutrients of algae. The adverse effects of the abundance of nutrient concentrations of phosphate and nitrate in waters are the occurrence of algae bloom in Karang Kates reservoir (Brahmana, 2002). The densely packed algae population in the reservoir is scattered on the edges of the reservoir, especially in the bay.

The discharge of pollutants which is derived from industrial waste, such as oil and gas, palm oil, and coal, and domestic activities, into Mahakam river basin, is also a factor contributing to the declining of the 
carrying capacity of the Mahakam river basin including Lake Jempang (Ghitarina et al., 2009). This can disrupt the balance of the Lake Jempang and cause a decrease in the function of the environment. Therefore, the aim of this study was to find out the status of Lake Jempang through its plankton and benthos communities.

\section{MATERIALS AND METHODS}

The location of the study administratively located in West Kutai. The research stations consisted of six sampling points representing the existing conditions and activities around the Lake Jempang. They are: 1 middle part of Lake Jempang, and 5 villages: Muara Ohong, Jantur, Pulau Lanting, Tanjung Jone, and Tanjung Isuy.
The primary and secondary data were collected using survey method by observing, sampling, identifying and calculting plankton and benthos indexes. Plankton and benthos community structure was analyzed by counting the abundance, and uniformity, diversity, and dominance indexes.

\section{Plankton}

\section{RESULTS}

The species composition and abundance, diversity index $\left(\mathrm{H}^{\prime}\right)$, uniformity index $\left(\mathrm{E}^{\prime}\right)$ and the dominant index $\left(\mathrm{D}^{\prime}\right)$ of plankton in Lake Jempang are presented in Table 1. There were 8 classes of plankton found in the lake, consisted of 5 classes of phytoplankton and 3 classes of zooplankton. Gomphosphaeria aponina belongs to Cyanophyceae class and Tabellaria floculos from Rotifers class were abundantly found in all sampling locations.

Table 1. Plankton species collected from Lake Jempang at each sampling stations during survey.

\begin{tabular}{|c|c|c|c|c|c|c|c|}
\hline \multirow[b]{2}{*}{ No. } & \multirow[b]{2}{*}{ Species of Plankton } & \multicolumn{6}{|c|}{ Location of Sampling } \\
\hline & & $\begin{array}{l}\text { Muara } \\
\text { Ohong }\end{array}$ & $\begin{array}{l}\text { Middle } \\
\text { of Lake }\end{array}$ & Jantur & $\begin{array}{c}\text { Pulau } \\
\text { Lanting }\end{array}$ & $\begin{array}{c}\text { Tanjung } \\
\text { Jone }\end{array}$ & $\begin{array}{c}\text { Tanjung } \\
\text { Isuy }\end{array}$ \\
\hline A. & Phytoplankton & & & & & & \\
\hline \multirow[t]{12}{*}{1} & Chlorophyceae & & & & & & \\
\hline & Ankistrodesmus sp & & & & & & 189 \\
\hline & Chlamydomonas sp & & 126 & 252 & 441 & 252 & \\
\hline & Desmidum sp & & & 126 & & & \\
\hline & Lagerheimia sp & 315 & 189 & 630 & 2709 & & 3402 \\
\hline & Microspora sp & 63 & 756 & & & & 126 \\
\hline & Palmella sp & 252 & 63 & & 441 & 441 & 126 \\
\hline & Pediastrum sp & & 126 & & 63 & & 315 \\
\hline & Pleurotaenia ehrenbergii & & & & & 1134 & \\
\hline & Spirogira sp & & & & & 63 & 189 \\
\hline & Staurastrum sp & & 63 & & & 63 & \\
\hline & Ulothrix aequalis & 252 & 1638 & 2835 & & 567 & 504 \\
\hline \multirow[t]{3}{*}{2} & Cyanophyceae & & & & & & \\
\hline & Gomphosphaeria aponina & 441 & 504 & 126 & 315 & 819 & 441 \\
\hline & Microcystis sp & 945 & 189 & & & 441 & 252 \\
\hline \multirow[t]{4}{*}{3} & Crysophyceae & & & & & & \\
\hline & Asterionella sp & & & 126 & & 126 & \\
\hline & Surirella robusta & & 63 & & & & 126 \\
\hline & Tabellaria floculos & 63 & 189 & 1890 & 189 & 504 & 567 \\
\hline
\end{tabular}




\begin{tabular}{|c|c|c|c|c|c|c|c|}
\hline \multirow[t]{2}{*}{4} & \multicolumn{7}{|l|}{ Dinophyceae } \\
\hline & Peridinium $\mathrm{sp}$ & & & 189 & 3213 & 2016 & 3024 \\
\hline \multirow[t]{2}{*}{5} & Closteriaceae & & & & & & \\
\hline & Pachyladon umbrinus & & & 189 & & 126 & 126 \\
\hline \multirow{6}{*}{$\begin{array}{c}\text { B. } \\
1\end{array}$} & Zooplankton & & & & & & \\
\hline & Rotifer & & & & & & \\
\hline & Euchlanis sp & 315 & 126 & & 504 & 126 & 252 \\
\hline & Keratella sp & 252 & & 189 & & 63 & 126 \\
\hline & Philodina sp & 63 & & & & & \\
\hline & Proales sp & & & & & 63 & \\
\hline \multirow[t]{4}{*}{2} & Crustacea & & & & & & \\
\hline & Copepod nauplius & 252 & & & 378 & 378 & \\
\hline & Dapmina sp & 126 & 63 & & 441 & & \\
\hline & Diaptomus sp & & & & 504 & 189 & \\
\hline \multirow[t]{4}{*}{3} & Euglenaceae & & & & & & \\
\hline & Euglena sp & & & & 189 & 126 & 126 \\
\hline & Phacus sp & & 63 & 252 & 441 & 189 & \\
\hline & Trachelomonas sp & 126 & 63 & 189 & 819 & 441 & 315 \\
\hline \multicolumn{2}{|c|}{ Individual Plankton/Liter } & 3465 & 4221 & 6993 & 10647 & 8127 & 10017 \\
\hline \multicolumn{2}{|c|}{ Numbers of Class } & 13 & 15 & 12 & 14 & 20 & 16 \\
\hline \multicolumn{2}{|c|}{ Index of Diversity $\left(\mathrm{H}^{\prime}\right)$} & 2.27 & 2.04 & 1.78 & 2.12 & 2.52 & 1.99 \\
\hline \multicolumn{2}{|c|}{ Index of Equitability (E') } & 0.89 & 0.75 & 0.7 & 0.80 & 0.84 & 0.72 \\
\hline \multicolumn{2}{|c|}{ Index of Dominance (D') } & 0.13 & 0.21 & 0.25 & 0.18 & 0.11 & 0.22 \\
\hline
\end{tabular}

The plankton species composed of Chlorophyceae (42\%), Cyanophyceae (10\%), Crysophyceae (9\%), Dinophyceae (19\%), and Closteriaceae (1\%). The highest abundance of plankton was found in phytoplankton of Chlorophyceae class 18,207 ind./L, and the lowest was from Closteriaceae class 441 ind./L. There were 1-10 species of phytoplankton identified with abundance ranged from 63 to 3,402 ind./L. There were only 3-4 species of zooplankton identified in the locations, with average abundance of 63-
819 ind./L. The common zooplankton found was from Euglenaceae (8\%), followed by Rotifer and Crustacea (5\%) (Figure 1).

Diversity index of plankton found in the waters of Lake Jempang ranged between 1.78 and 2.52. Based on the criteria of diversity index $\left(\mathrm{H}^{\prime}\right)$, all sampling stations in general have diversity of species classified as moderate $\left(H^{\prime}=1-3\right)$. Equity index of plankton at each station obtained during this study ranged from 0.70 to 0.89 . Dominance index during the study ranges from 0.11 to 0.25 . 


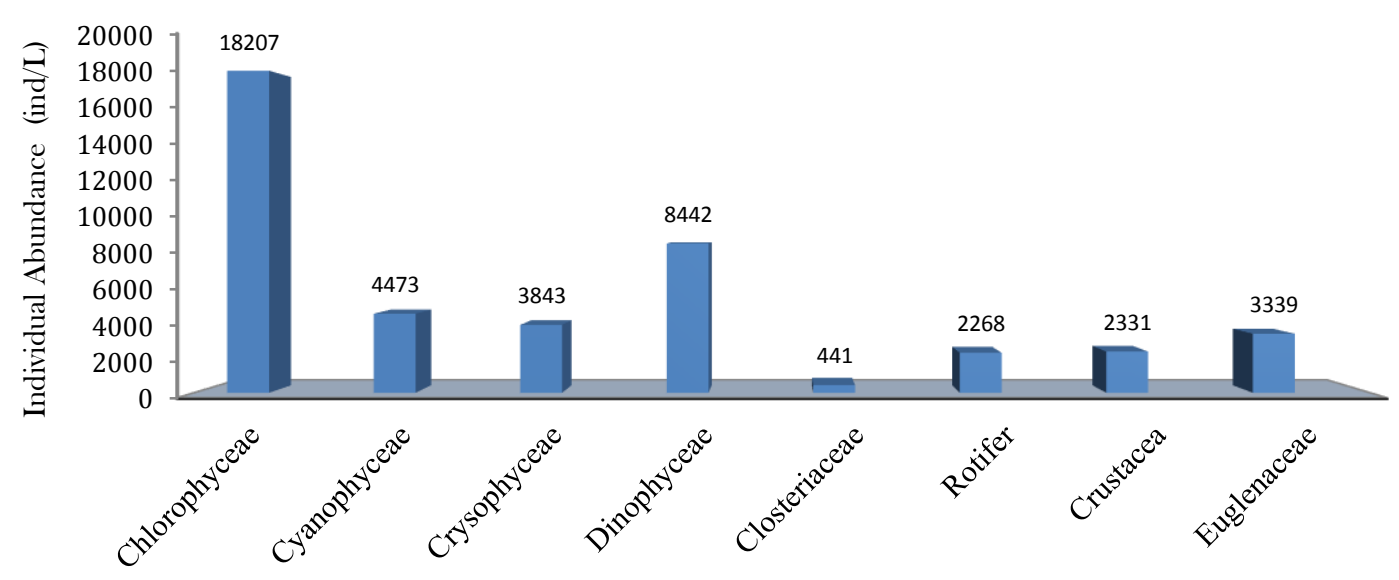

Figure 1. Total individual abundance of varies classes of plankton identified in Lake Jempang.

\section{Benthos}

The type and abundance of benthos at 6 stations in Jempang were relatively low. Two phyla of benthos were identified with an abundance of varied consisting of phylum Gastrophoda ( 2 species) and the phylum Pelecypoda (1 species) (Table 2)

Tabel 3. Benthos collected from Lake Jempang at each Sampling Stations during survey

\begin{tabular}{llccccc}
\hline \multirow{2}{*}{ No. $\quad$ Species of Benthos } & \multicolumn{6}{c}{ Location } \\
\cline { 2 - 7 } & $\begin{array}{c}\text { Muara } \\
\text { Ohong }\end{array}$ & $\begin{array}{c}\text { Middle } \\
\text { Lake }\end{array}$ & Jantur & $\begin{array}{c}\text { Pulau } \\
\text { Lanting }\end{array}$ & $\begin{array}{c}\text { Tanjung } \\
\text { Jone }\end{array}$ & $\begin{array}{c}\text { Tanjung } \\
\text { Isuy }\end{array}$ \\
\hline A. Gastropods & & & & & & \\
1. Bellamya Javanica & 3 & 5 & 4 & 5 & 6 & 3 \\
2. Pomacea Canaliculata & - & 2 & - & 2 & 3 & 4 \\
B. Pelecypoda & & & & & & \\
1. Corbicula sp & 6 & 10 & 4 & 7 & 8 & - \\
& & & & & & \\
Individual Plankton/Liter & 9 & 17 & 8 & 14 & 17 & 7 \\
Numbers of Class & 2 & 3 & 2 & 3 & 3 & 2 \\
Index of Diversity (H') & 0.64 & 0.92 & 0.69 & 0.99 & 1.02 & 0.68 \\
Index of Equitability (E') & 0.92 & 0.84 & 1 & 0.90 & 0.94 & 0.98 \\
Index of Dominance (D') & 0.56 & 0.45 & 0.50 & 0.40 & 0.38 & 0.51 \\
\hline
\end{tabular}

Total individual abundance of benthos ranged from $7 \mathrm{ind} / \mathrm{m}^{2}$ to $17 \mathrm{ind} / \mathrm{m}^{2}$. Benthos types that most commonly found are of the phylum Gastrophoda with the highest abundance of $37 \mathrm{ind} / \mathrm{m}^{2}$ with the most abundant species of in all stations, Bellamya javanica; while the lowest abundance of benthos comes phylum Pelecypoda (35 ind. $\left./ \mathrm{m}^{2}\right)$. In phylum Gastrophoda, there are 2 species identified and with abundance of 0-6 ind. $/ \mathrm{m}^{2}$ at each station; whereas phylum Pelecypoda only one species identified with an abundance between $0-10$ ind. $/ \mathrm{m}^{2}$ at each stations. 


\section{DISCUSSIONS}

In general, Lake Jempang is quite rich on plankton. It can be seen from the number species and the abundance at all sampling locations. Plankton species in Lake Jempang are mostly from Chlorophyceae, Cyanophyceae and Chrysophyceae, which can be directly utilized by first level consumers or zooplankton. The high abundance of these fitoplankton in Lake Jempang influenced by the nutrients that exist in those waters. Nutrients can include silicates, the main component constituent cell types of plankton. In addition to silicates, nutrient or nutrients that play a role in the growth of phytoplankton are nitrate (NO3-N) and phosphate (PO4-P).

The abundance of plankton in each station allegedly affected by environmental factors including brightness, current, and nutrients in every station in this case the content of the existing water quality in the waters. Different plankton abundance in each station could be due to several environmental factors such as brightness, current, and nutrients at each station in this case the water quality content in the waters. Total abundance of individual plankton in Lake Jempang varies among sampling stations.

The diversity index values indicate that the diversity of plankton in the locations is in medium category. This shows that the stability of the community of organisms is in moderate level, meaning that the condition of the community at all sampling locations easily changed only by experiencing a relatively small environmental impact. The Equity index of plankton at each station obtained during this study suggests that the composition of the plankton community structurer is relatively balanced, and no species dominate the community structures in these waters or the numbers of individuals among species that make up the aquatic communities are relatively similar (Basmi, 2000). This means that at these stations, each species were able to adapt and compete in the utilization of mineral nutrients good and balanced.
The range of uniformity index value of plankton in Lake Jempang is quite large. The greater the uniformity index value of an aquatic organism (close to 1), the abundance of each species are relatively more evenly between stations. It is also correlated to the utilization of nutrients between the stations. Based on environmental criteria, plankton community conditions that exist in these waters are categorized as unstable to stable condition, but more likely in unstable condition. It can be seen from the change of plankton species during the study. Dominance index values showed no dominant plankton species among the sites was observed. Although there are certain types that always appear in the observation but showed no dominance of their abundance.

In general, benthos community in Lake Jempang has very low stability. It is presumed that the organic material in the bottom of the waters and the source of food has been so little that it can no longer support the life of benthos organisms. The presence of Gastrophoda phyla in some of the side sites (stations) in Lake Jempang suggests that this location is perfect for their lives, especially Bellamya javanica, which is a species that is able to live very well in the subtrates in the bottom waters associated with mostly sandy mud and high organic matter and this type has a high adaptability to the poor environment.

\section{CONCLUSIONS}

In general the quality of phytoplankton that found in Lake Jempang is quite good in which mostly the type favored by fish larvae and plankton-eating fish. While the number of species and abundance of zooplankton species are relatively lower. The diversity, equitability and dominance indexes of plankton in Lake Jempang showed that the Lake is in moderate condition and no particular type of plankton dominates. While the species variety and abundance of benthos in Lake Jempang is very low. 


\section{ACKNOWLEDGEMENT}

Our gratitude goes to the Directorate General of Higher Education and to the Research Institution of Mulawarman University for the funding and facilities given.

\section{REFERENCES}

Angeler DG, Baho DL, Allen CR. et al. 2015. Linking degradation status with ecosystem vulnerability to environmental change. Oecologia, 178: 899. https://doi.org/10.1007/s00442015-3281-y

Basmi HJ. 2000. Planktonologi: Plankton sebagai Indikator Kualitas Perairan. Bogor: Fakultas Perikanan dan Ilmu Kelautan, Institut Pertanian Bogor. Bogor

Brahmana SS, Suyatna U, Fanshury R, Samsul B. 2002. Pencemaran Air dan Eutrofikasi Waduk Karang Kates dan Upaya Penanggulangannya. Jurnal Puslitbang Pengairan, 16(49): 73-81

Ghitarina, Abdunnur, Eryati R. 2009. Monitoring of water Quality and Pollution in the Mahakam Watershed. 1 Natural Life, Vol. 4, December No.1, ISSN : 1829-653X
Abate M, Nyssen J, Moges MM, Enku T, Zimale FA, Tilahun SA, Adgo A, Steenhuis TS. 2017. Long-term Landscape changes in the Lake Tana Basin as Evidenced by Delta Development and Floodplain Aggradation in Ethiopia. Land Degradation and Development. 28(6): 18201830, https://doi.org/10.1002/ldr.2648

Risamasu FJL, Prayitno HB. 2011. Kajian Zat Hara Fosfat, Nitrit, Nitrat dan Silikat di Perairan Kepulauan Matasiri Kalimantan Selatan. Ilmu Kelautan, 16(3): 135-142 ISSN 0853-7291

Taoa S, Fanga J, Zhaob X, Zhaoa S, Shenb H, Hub H, Tanga Z, Wanga Z, Guob Q. 2015. Rapid loss of Lakes on the Mongolian Plateau Current Issue. In Proceedings of National Academy of Sciences of the United States of America. 112(7): 2281-2286 https://doi.org/10.1073/pnas.141174811

Wang S, Meng W, Jin X, Zheng B, Zhang L, Xi H. 2015. Ecological security problems of the major key lakes in China. Environmental Earth Sciences, 74(5): 3825-3837.

https://doi.org/10.1007/s12665-015-4191-3 